\title{
Sectorial Performance and Inclusive Growth in Nigeria (1990 - 2013): An Assessment
}

\author{
Ozurumba Benedict Anayochukwu ${ }^{1}$, Onuorah Anastasia Chi-Chi ${ }^{2}$ \\ ${ }^{1}$ Department of Management Technology, Federal University of Technology, \\ Owerri, Imo State, Nigeria \\ ${ }^{2}$ Department of Accounting, Banking \& Finance, Delta State University, Asaba, \\ Delta State, Nigeria
}

\begin{abstract}
This work assessed sectorial performance on inclusive growth in Nigeria for the period 1990 - 2013. The study was necessitated by the fact that the economy is often said to be growing but such growth is not inclusive in the real sense of it. Many Nigerians are still living below the poverty line. The study made use of secondary data in its analysis. Six explanatory variables (Agricultural Sector GDP, Oil and Gas GDP, Telecommunication sector GDP, Manufacturing sector GDP, Financial institutions sector GDP and electricity sector GDP) were specified and used to establish a relationship with Human Development Index and Gross Domestic Product Per Capita using the Vector Autoregressive (VAR) approach. Other tests carried out include: stationary, counteraction and Granger causality tests. The study found that the selected explanatory variables have no significant relationship with Gross Domestic Product Per Capita. While only Agricultural Sector GDP and Telecommunication sector GDP have significant relationship with Human Development Index, other variables are not statistically significantly at $5 \%$ level. Based on the findings the work concludes that the above selected sectors of the economy have not contributed significantly to the development of the Nigerian economy. The researcher recommends among others that financial sector services to the real sector should be sustainable to stimulate economic activities in a manner that creates linkages across economic value chains that will assure development in the long run.
\end{abstract}

Key words: Growth, Development, Inclusive growth, Living standard, Per capita income, Sectorial performance

\section{INTRODUCTION}

In the 1970 s and 1980s, the pre-occupation of economic planning was on growth (increasing output). Growth was seen as prerequisite for improved standard of living. Many developing countries, including Nigeria with support from World Bank and International Monetary Fund (IMF) embarked on various forms of economic reforms and adjustments all aimed at promoting growth, with an underling assumption that poverty will disappear if growth is achieved. The above postulation worked for few countries, and never worked for many, Nigeria inclusive. Hence, a paradigm shift away from the conclusion that fast and high growth leads to poverty reduction. However, evidence from many countries that experienced high growth, including Nigeria showed that incidence of income inequality was equally raising faster than the rate at which growth was recorded, suggesting that it is not the speed and rate of high growth that really matters in addressing problem of economic exclusion, but the structure of growth and its distributive effects. The implication being that fast and high growth can lead to non-inclusive growth if equitable access and opportunity to national resources is not guaranteed, especially for the vulnerable and under-privileged groups. The apparent lack of the above situation has led to a situation where high growth has widened the gap between the rich and the poor, 
as well as eroded the middle class in Nigeria. This contradicts earlier theories of development that promoted extreme capitalism which suggested that inequality is good for growth and an incentive for poverty reduction through growth. Particular attention must now be placed on sustained positive correlation between sectorial performance and inclusive growth in Nigeria. The recent re-basing of Nigeria based on GDP growth which puts her as the biggest economy in Africa equally demand attention with the objective of identifying why the Nigerian economy is growing without leading to enhanced standard of living. The structural adjustment programme (SAP) policies of the 1980s, which continued in varying degrees till the late 1990s, has equally been sustained since the inauguration of the new democratic government in 1999 as series of reforms (National Economic Empowerment and Development Strategy (NEEDS); Vision- 20-2020) have been introduced.

These theoretical and empirical divergences on inclusive growth in developing economies have continued to elicit public debate on the degree of performance of the various sectors in our economy. Thus, it is important to investigate and see the picture presented by Nigerian data in this regard. This is essential considering the growth trends in recent time of some selected key sectors in Nigeria, their contributions to poverty alleviation and general improvement on the welfare of the citizenry has been a source of concern. Thus, one may wish to ask, to what extent has the various sectorial performances such as agriculture, manufacturing, energy and services affected the level of economic development of Nigeria? This paper investigates the long run relationship between sectorial performance and inclusive growth in Nigeria for the period 1990-2013. This work will extend the frontiers of literature in respect of the Nigerian experience as most of the previous studies have focused on a single sector analysis.

The paper is organized into five sections which include: the introduction, review of related literature methodological issues, empirical findings and finally conclusion.

\section{LITERATURE REVIEW}

2.1 Conceptual Framework

According to the World Bank (2000), growth is said to be inclusive when the growth is to be sustainable in the long run and should be broad based across the sector and inclusive of large part of countries labour force. Inclusiveness should be understood in the sense and focusing on equality of opportunity in terms of access to markets, resources and unbiased regulatory environment for business and individual (George, 2011).

The African Development Bank (AfDB) also pays central attention to the rate and pattern of growth, considering long-term, sustainable high economic growth necessary to reduce poverty and growing productive employment necessary to concomitantly reduce inequality (AfDB, 2012). In this perspective, the AfDB defines inclusive growth as "economic growth that results in a wider access to sustainable socio-economic opportunities for a broader number of people, regions or countries, while protecting the vulnerable, all being done in an environment of fairness, equal justice, and political plurality" (AfDB, 2012: 2). Also, Elena and Susana (2010) believe that growth can only be said to be inclusive when it allows people to contribute to and benefit from the growth process by reducing poverty. Anders \& Sparling (2013) sees inclusive growth in terms of growth that is delivered by the inclusion of more people in the production of wealth, allowing them to benefit from overall economic development. Rainer \& Ramos (2013) argued that inclusive growth involves improving the lot of underprivileged people in particular and overall making opportunities more plentiful while lessening barriers to the attainment of better living conditions.

The overall goal in development is therefore the provision of the basic needs, acceleration of economic growth, reduction of inequality and unemployment, eradication of absolute poverty as well as changes in attitudes, institutions and structures (political, civil rights of all people across gender, religions and races) in the economy. Economists have traditionally considered an increase in per capita income to be a good proxy for other attributes of development. But the weakness in income growth as an indicator is that it may mask the real change in welfare for large parts of the poor population. 
Improvement in meeting basic needs for food, education, healthcare, and equity of opportunity, civil liberties, and environmental protection are not captured by statistics of income growth (Onwioduokit, 1998). Although different cultures place different values on the various elements of development, broadly defined, most seek improvements in every dimension.

\section{THEORETICAL FRAMEWORK}

The post-World War II literature on economic development has been dominated by four major And sometimes competing strands of thought

- the linear-stages-of-growth model,

- theories and patterns of structural change,

- the international-dependence revolution, and

- the neoclassical, free-market counterrevolution

The linear-stages-of-growth model: The stages of growth model of development, was advocated by an American economic historian W.W. Rostow (1960). This school of thought focused on the lack of domestic savings and investment. In order to promote growth, policymakers had to induce higher savings and investment rates in developing countries. The model postulates that economic modernization occurs in five basic stages, of varying length: the traditional society, the preconditions for take-off into self-sustaining growth, the take-off, the drive to maturity and the age of high mass consumption. He further stated that one of the principal strategies of development necessary for takeoff was the mobilization of domestic and foreign savings to generate sufficient investment to accelerate economic growth. This view assumes that domestic and foreign savings only are sufficient for growth. The theory was supported by the Harrod-Domar model (1946) which demonstrated that countries with higher savings ratio are expected to grow faster than those with lower rates and that the main obstacle to or constraint on development is the relatively low level of new capital formation in most developing countries (Todaro and Smith, 2009).

According to the proponents of the structural change model, Structural-change theory deals with policies focused on changing the economic structures of developing countries from being composed primarily of subsistence agricultural practices to being a "more modern, more urbanized, and more industrially diverse manufacturing and service economy". In Lewis' (1954) two-sector model or theory of surplus labour, labour increasingly moves away from the agricultural sector to the industrial sector. However, with unlimited supply of labour from the traditional sector, these transferred workers continually received only subsistence wages. The excess of modern sector profits over wages and hence investments in the modern sector continued to expand and generate further economic growth on the assumption that all profits would be reinvested.

Given the failure of the Lewis model to meet the challenges of the realities of contemporary developing countries, the International-Dependence Revolution model which postulates that developing countries are economically and politically dependent on more powerful, developed countries which have an interest in maintaining their dominant position (Hein 1992). There are three different, major formulations of international dependence theory; neo-colonial dependence theory, the false-paradigm model and the dualistic-dependence model.

In the 1980s, neoclassical counter-revolution economists used three approaches, market-friendly approach, to counter the international dependence model. In contrast with the international dependence model, these approaches mainly argued that underdevelopment is not the result of the predatory activities of the developed countries and the international agencies but was rather caused by the domestic issues arising from heavy state intervention such as poor resource allocation, government-induced price distortions and corruption (Meier 2000).

Neoclassical economists focused on the market to find a way out for the developing countries. Policies of liberalization, stabilization and privatization therefore become the central elements of the national development agenda. Foreign trade, private international investments and foreign aid flowing into the 
developing countries are expected to accelerate economic efficiency and economic growth of these countries. Empirically, the models, however, did not bring about the expected results. The growth rates per capita have diverged among countries (Azariadis and Drazen 1990).

These theories and many others like them are not without their shortcomings but, as is usual of theories, they are merely representations of reality and not reality itself. The critical message from them is that development is multidisciplinary and that notwithstanding their shortcomings, each of them still captures some aspects, at least, of the challenges of contemporary developing countries.

\subsection{Growth Trends}

\subsubsection{Relationship between Growth indicators and Sectorial Performance indicators}

An analysis of the sectorial contributions to GDP revealed that the share of agriculture in GDP averaged 40.3 per cent during the period 1999-2011. It was 36.7 per cent in 1999; peaked at 43.9 per cent in 2000 and stabilized at 40.2 per cent in 2011(CBN, 2013:10). Eluhaiwe (2010) noted that, agricultural production in Nigeria is heavily dependent on smallholder farmers who adopt manual approaches to farming. Also, only a small fraction of the smallholder farmers have access to finance. The condition under which these subsistence farmers operate which includes lack of access to technology, high covariance risk, lack of access to farm inputs, lack of financial literacy, resistance to change and other challenges, culminate into low yield and poor income.

Industry as a whole contributed only 11.3 per cent of the GDP in 1960-70, growing significantly in the next two decades to a high of 41.0 per cent in 1981-1990, owing largely to the crude petroleum and gas production during the decades. The contribution contracted to 38.6 per cent in the $1990 \mathrm{~s}$ and further to 29.4 per cent during 2001-2009 (CBN, 2013). These numbers, in fact, belie the poor contribution of the manufacturing sub-sector to aggregate output in Nigeria compared with its peers in Asia and Latin America.

Political and economic factors contributed greatly to the decline in the manufacturing sectors. For instance, poor infrastructure and epileptic power supply are key impediments to the industry. The industry as a whole operates on more than $70 \%$ of energy it generates, using generators. And operating these generators greatly increases the cost of manufacturing goods. Other factors include increase in the prices of petroleum products used by industries, multiple taxation, unabated smuggling and inadequate access to finance, both locally and abroad.

The country's telecommunication sector is undergoing speedy transformation on account of explosive growth and rapid infrastructure developments. Liberalisation of the telecom sector along with increased competition among players have brought substantial benefits to the consumers in terms of lower subscription rates and enhanced choice. Moreover, the Nigerian government is making efforts to transform the country's economy into a knowledge-based economy.

Nigeria's financial system is still shallow as majority of Nigerians lack access to formal financial services provider. The financial sector accounts for about 3\% of the GDP. The wide consensus that credit from banks and other financial institutions play an important role in generating growth and reducing poverty is in no doubt. This is because availability of credit facilities enhances the purchasing power of individuals and households, and this has a multiplier effect on the economy of any nation. However, most banks in Nigeria have historically tended to concentrate lending to the corporate and commercial segments of the market, thereby locking out the retail/consumer segment from the credit system; largely on account of the lack of credit information on individuals and persons in the country, which make up that segment. 
Ozurumba Benedict Anayochukwu, Onuorah Anastasia Chi-Chi

Sectorial Performance and Inclusive Growth in Nigeria (1990 - 2013): An Assessment

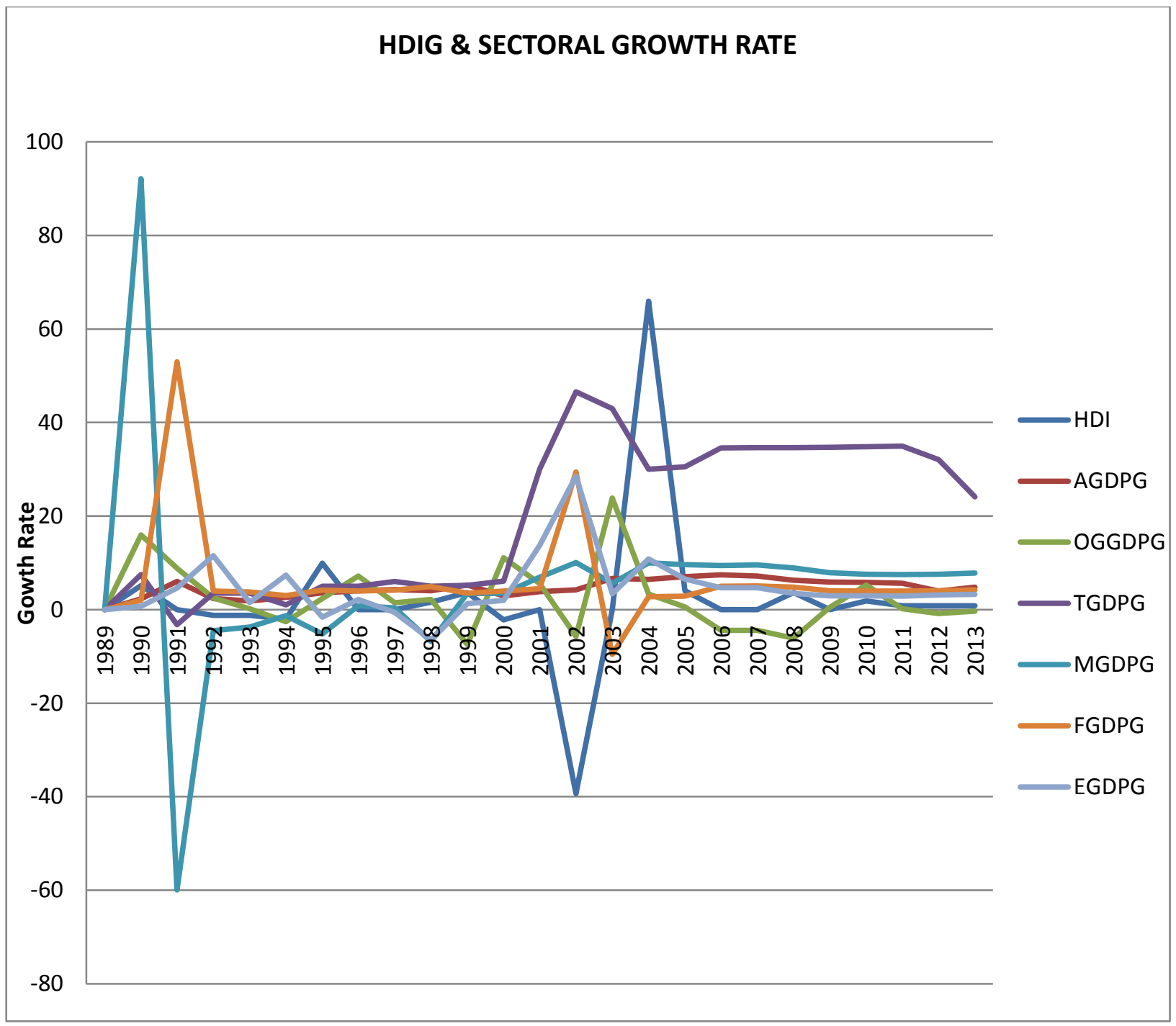

Figure 1a: Human Development Index and Sectorial Growth Rates (Before rebase)

Source: CBN Statistical Bulletin 2013

Considering the relationship between HDI and sectorial performance growth, figure 1 shows an erratic movement of the sectors. However, sharp drops could be noticed in the graph. Manufacturing sector rose to its highest positive peak in 1990 and dropped sharply in 1991. Nevertheless, from the year 2010, the sectors witnessed a steady but almost straight movement. Conversely, telecommunication sector which was growing steadily began to fall. Also, between the 2005 and 2009, Oil and Gas sector had negative growth. The graph shows that within these years Oil and Gas growth rate was lower than HDI growth rate. The sectors contribution to economic growth has not been inclusive. 
Ozurumba Benedict Anayochukwu, Onuorah Anastasia Chi-Chi

Sectorial Performance and Inclusive Growth in Nigeria (1990 - 2013): An Assessment

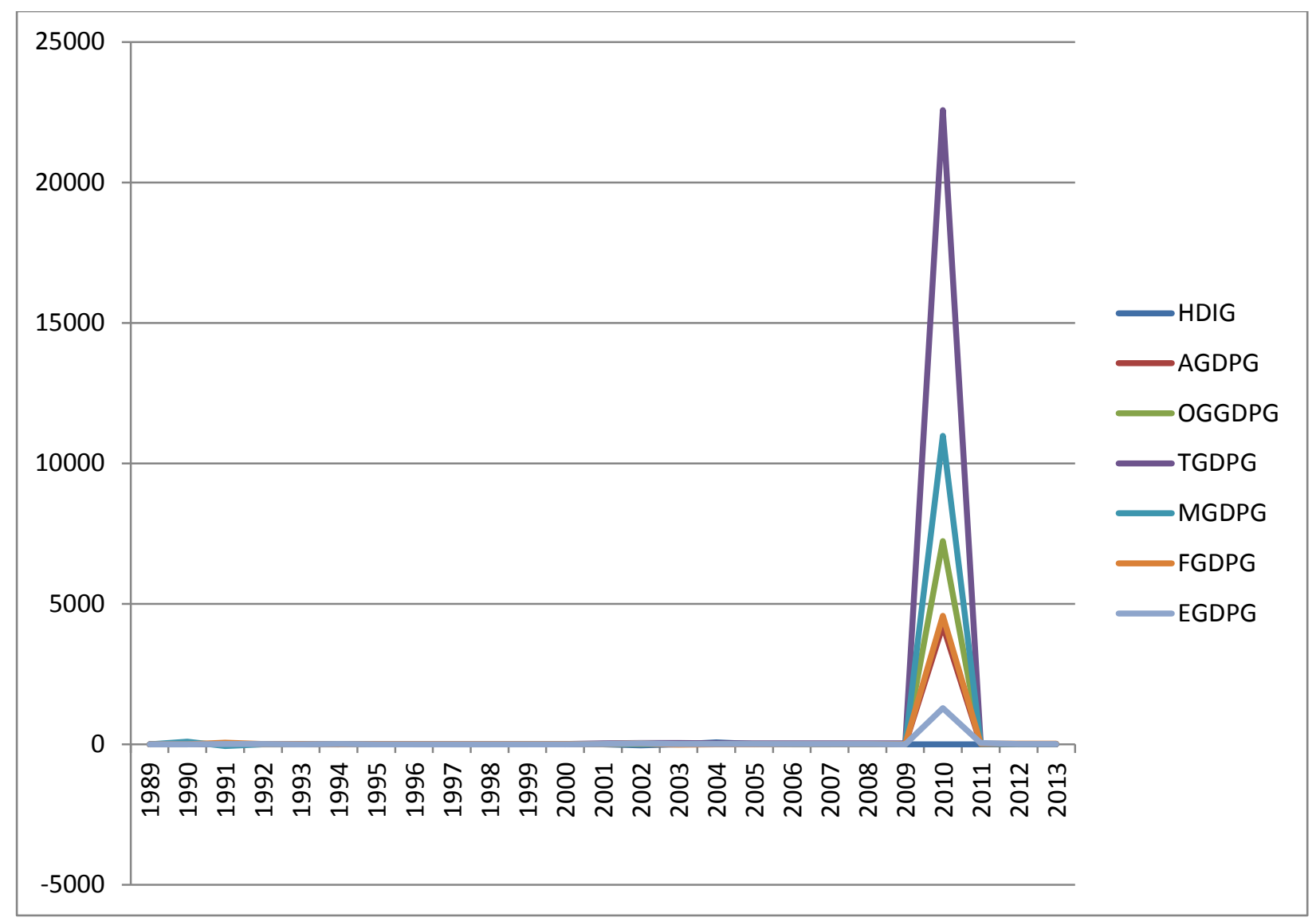

Figure 1b: Real GDP Per Capita and Sectorial Growth Rates (After rebase)

Source: CBN Statistical Bulletin 2013

This situation did not change even after the economic rebase in 2010 as shown in $1 \mathrm{~b}$. Implementation of the rebase policy forced a sharp increase in 2011. This created a wrong belief that the economy has grown. However, looking at the movement the graph after 2010, it shows that the sectorial performance growth rate returned to its growth style before the implementation of the rebase policy. 
Ozurumba Benedict Anayochukwu, Onuorah Anastasia Chi-Chi

Sectorial Performance and Inclusive Growth in Nigeria (1990 - 2013): An Assessment

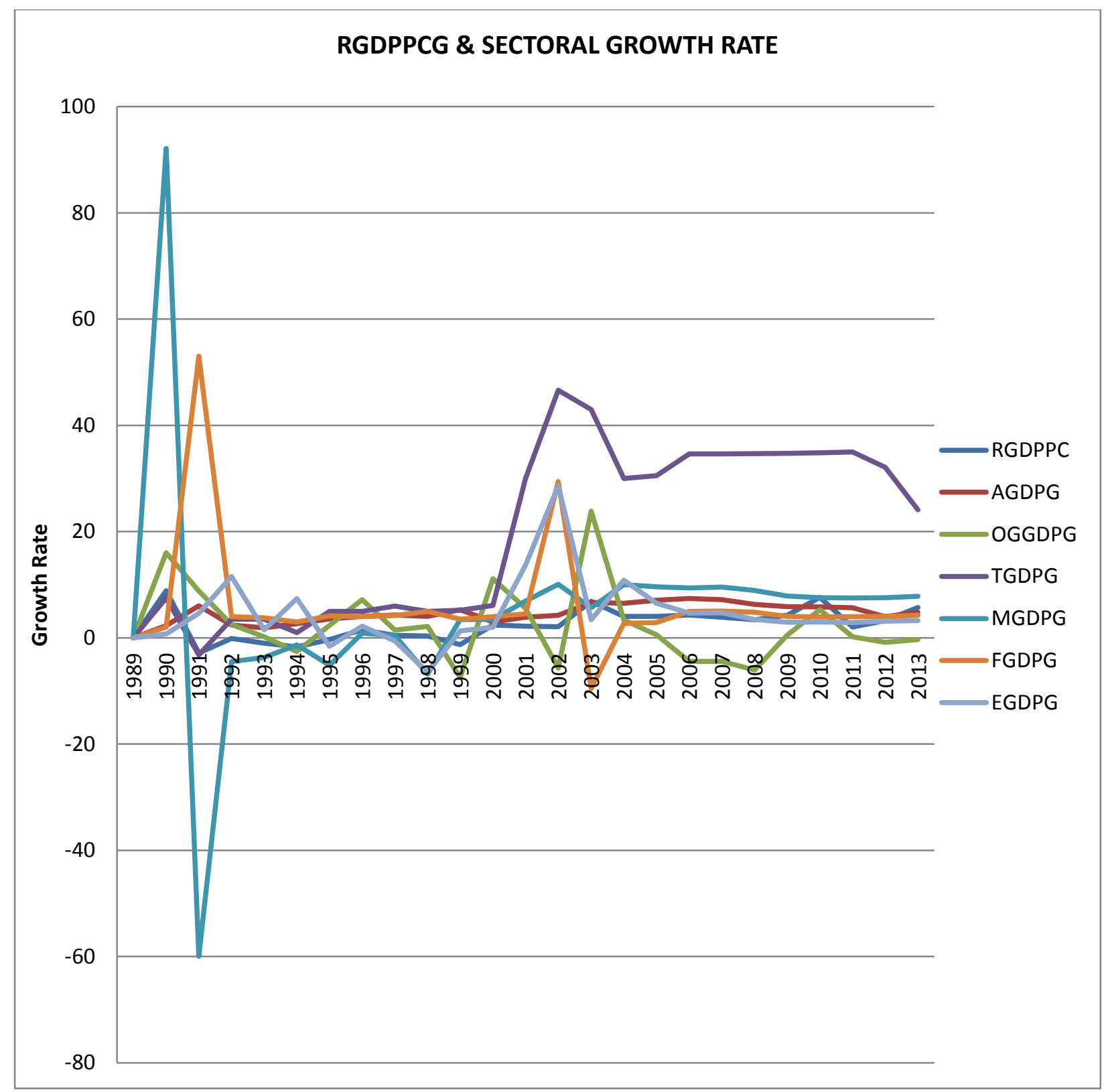

Figure 2a: Real GDP Per Capita and Sectorial Growth Rates (Before rebase)

Source: CBN Statistical Bulletin 2013

Considering the relationship between RGDPPCG and sectorial performance growth, figure $2 a$ also shows an erratic movement of the sectors. Sharp drops could be noticed in the graph between 1989 and 1990, 2000 and 2003. Manufacturing sector rose to its highest positive peak in 1990 and dropped sharply in 1990 while it got to its lowest peak in 1991 . Between 1992 and 2000 the sectorial growth rate was erratic. Some (MGDPG and EGDPG) even falling to negative. The period 2000 to 2004 witnessed another dramatic movement. Within this period, TGGDPG reached its highest peak in 2003. OGGDP maintained a negative growth between 2005 and 2009 while the other sectors maintained almost a steady growth during the same period. The graph shows that within these years Oil and Gas growth rate was lower than GDPPC growth rate. Nevertheless, from the year 2010, the sectors witnessed a steady but almost straight movement with OGGDP climbing to positive growth. Conversely, telecommunication sector which was growing steadily began to fall. The sectors contribution to economic growth has not been inclusive. RGDPPC did not grow adequately. 


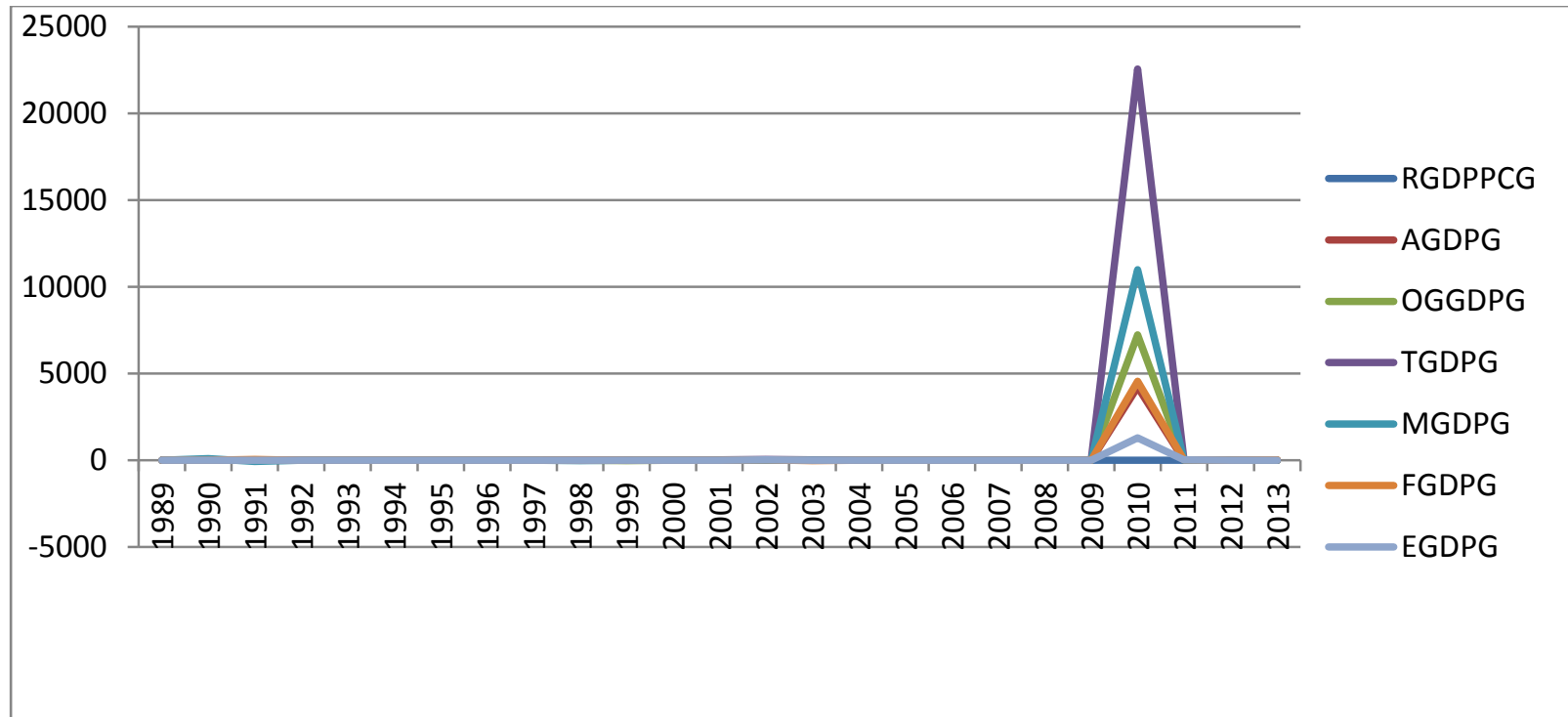

Figure 2b: Human Development Index Growth and Sectorial Growth Rates (After rebase)

Source: CBN Statistical Bulletin 2013

This situation did not change even after the economic rebase in 2010 as shown in figure $2 b$. Implementation of the rebase policy forced a sharp increase in growth rate in 2011. This created a wrong belief that the economy has grown tremendously. However, looking at the movement of the graph after 2010, it shows that the sectorial performance growth rate returned to its growth style before the implementation of the rebase policy while HDI (fig1a) as well as GDPPC (Fig 2a) did not witness any growth corresponding to the level of growth displayed by the sectors. This therefore shows that though the economy is growing but such growth is not all inclusive considering the levels of HDI and GDPPC.

\section{METHODOLOGY}

\subsubsection{Model Estimation Procedures}

This paper shall employ econometric tools of unit root test, counteraction test, Granger causality and Vector autoregressive (VAR) approach. The descriptive analysis will also be incorporate to determine the nature of the data set. The variables were transformed to their logarithm for estimation in order to bring them to the same unit. The study would employ secondary data extracted from the Central Bank of Nigeria Statistical Bulletin and Annual Reports covering a period of 24 years (1990-2013).

\subsubsection{Unit Root Test}

Dickey and Fuller looked at the distribution of this kind of test statistic and found that OLS estimates are biased down (towards stationary) and OLS standard errors. Thus, it is possible that many series that you would have thought were stationary based on OLS regression were in fact generated by random walks (Cochrane, 2005) we shall therefore subject all the variables to unit root test using the Augmented Dickey Fuller (ADF) test specified in Gujarati (2004) as follows.

$$
\Delta Y_{t}=\beta_{1}+\beta_{2}+\delta Y_{t-1}+\alpha i \sum_{i-1}^{m} \Delta Y_{t-1}+\varepsilon_{t}
$$

Where $\Delta \mathrm{Y}_{\mathrm{t}}=$ change in time $\mathrm{t}$

$\Delta \mathrm{Y}_{\mathrm{t}-1}=$ the lagged value of the dependent variables

$\Sigma_{\mathrm{t}}=$ white noise error term.

If in the above $\delta=0$, then we conclude that there is a unit root. Otherwise there is no unit root, meaning that it is stationary. The choice of lag will be determined by Akaike information criteria. 


\subsubsection{Co-integration Test}

Having confirmed the stationary of the variables, Co-integration test is carried out to show whether the variables are integrated (that is if they have a long term or equilibrium relationship between them (Koutsoyiannis, 2003). To test for this, the Johansen integration method would be employed.

Hypothesis to be tested is:

$H_{0}: \delta=0$ (the variables are not integrated).

$\mathrm{H}_{1}: \delta<0$ (the variables are integrated)

Decision Rule: Reject $\mathrm{H}_{0}$ if the statistic value exceeds the critical value at otherwise does not reject.

\subsubsection{Causality Test}

This test is used to show whether the contributions of the agaric GDP, Oil and Gas GDP, Telecommunication GDP, Manufacturing GDP, Financial Sector GDP and Electricity Sector GDP has cause human development index(HDI) and GDP Per Capita(GDPPC) to rise in Nigeria. To achieve this, the granger causality test will be employed.

The following hypotheses are tested:

$\mathrm{H}_{01}$ : Sectorial GDP contributions do not Granger causes HDI.

$\mathrm{H}_{02}$ : HDI does not Granger cause Sectorial GDP contributions.

$\mathrm{H}_{01}$ : Sectorial GDP contributions do not Granger causes GDPPC.

$\mathrm{H}_{02}$ : GDPPC does not Granger cause Sectorial GDP contributions.

Decision Rule: if the computed f-value exceeds the critical value at the chosen level of significance or the $\rho$-value is below $5 \%$, we reject the null hypothesis of no Granger Causality; otherwise do not reject the null hypothesis.

There is possibility of the following outcomes from the Granger causality test.

1. Unidirectional (from one variable to the other without feedback)

2. Bidirectional (from one direction to the other and vice versa i.e. with feedback)

3. No causality

\subsection{Model Specification}

It is obvious that before growth becomes all inclusive; it should be examined, looking beyond traditional monetary and output indicators to dimensions that reflect the quality of life of all participants in an economy. In this paper, we shall be interchanging inclusive growth with economic development. This study therefore, shall proxy inclusive growth with Human Development Index (HDI) and Gross Domestic Product Per Capita (GDPPC). In the same vein, we shall proxy the sectorial performance indicators (independent variables) with the output of the selected sectors so as to capture their aggregate contribution to economic development. The independent variables are Agricultural sector performance (AGDP), Oil and Gas performance (OGGDP), Telecommunication sector performance (TGDP), Manufacturing sector performance (MGDP), financial institutions performance (FGDP) and electricity sector performance (EGDP).

The functional specification of the models is:

$\mathrm{HDI}_{\mathrm{t}}=\mathrm{f}\left(\mathrm{AGDP}_{\mathrm{t}}, \mathrm{OGGDP}_{\mathrm{t}}, \mathrm{TGDP}_{\mathrm{t}}, \mathrm{MGDP}_{\mathrm{t}}, \mathrm{FGDP}_{\mathrm{t}}, \mathrm{EGDP}_{\mathrm{t}}\right)$

$\mathrm{GDPPC}_{\mathrm{t}}=\mathrm{f}\left(\mathrm{AGDP}_{\mathrm{t}}, \mathrm{OGGDP}_{\mathrm{t}}, \mathrm{TGDP}_{\mathrm{t}}, \mathrm{MGDP}_{\mathrm{t}}, \mathrm{FGDP}_{\mathrm{t}}, \mathrm{EGDP}_{\mathrm{t}}\right)$

Putting the equations in their natural logarithm form, the models become:

$\mathrm{HDI}_{\mathrm{t}}=\beta_{0}+\beta_{1}$ LnAGDP $_{\mathrm{t}}+\beta_{2}$ LnOGGDP $_{\mathrm{t}}+\beta_{3}$ LnTGDP $_{\mathrm{t}}+\beta_{4}$ LnMGDP $_{\mathrm{t}}+\beta_{5}$ LnFGDP $_{\mathrm{t}}+\beta_{6}$ LnEGDP $_{\mathrm{t}}+\mu_{\mathrm{t}}$

LnGDPPC $_{t}=\beta_{0}+\beta_{1}$ LnAGDP $_{t}+\beta_{2}$ LnOGGDP $_{t}+\beta_{3}$ LnTGDP $_{t}+\beta_{4}$ LnMGDP $_{t}+\beta_{5}$ LnFGDP $_{t}+\beta_{6}$ LnEGDP $_{t}+\mu_{t}$

Where: $\quad \beta_{1}, \beta_{2}, \ldots, \beta_{6}$ are the partial slope coefficients or parameters of the explanatory variables respectively. In addition, $\beta_{1}, \beta_{2}, \ldots, \beta_{6}$ represent the rate of change in the dependent variables for each unit change in independent variables respectively

$\beta_{0}$ is the intercept term or constant variable in the models.

$\mu_{t}$ is the disturbance or error term.

A priori expectations for the coefficients of the parameter are: $\beta 1>0, \beta 2>0, \beta 3>0, \beta 4>0, \beta 5>0, \beta 6$ $>0$ 
This means that we expect a positive functional relationship between dependent variables and the independent variables respectively.

\subsection{Empirical Statistics}

\subsubsection{Descriptive Statistic}

The descriptive statistics of variables used in the estimations for the two models, are presented in tables 4.1 and 4.2 .

Table 4.1: Descriptive Statistics of Variables in Model One

\begin{tabular}{|l|c|c|c|c|c|c|c|}
\hline & HDI & AGDP & OGGDP & TGDP & MGDP & FGDP & EGDP \\
\hline Mean & 0.435250 & 11.56818 & 11.35162 & 10.05767 & 10.64956 & 10.56204 & 10.38476 \\
\hline Median & 0.445000 & 11.27062 & 11.04124 & 9.462023 & 10.23528 & 10.28717 & 10.14741 \\
\hline Maximum & 0.504000 & 13.14714 & 12.96844 & 12.87667 & 12.68171 & 12.31657 & 11.75108 \\
\hline Minimum & 0.270000 & 11.08718 & 10.92474 & 9.091955 & 10.12306 & 9.898355 & 9.947852 \\
\hline Std. Dev. & 0.060297 & 0.722881 & 0.733070 & 1.328248 & 0.898820 & 0.760728 & 0.592084 \\
\hline Skewness & -1.595332 & 1.699167 & 1.763040 & 1.452324 & 1.719364 & 1.689398 & 1.631378 \\
\hline Kurtosis & 5.404434 & 4.036431 & 4.154037 & 3.538283 & 4.076827 & 4.061405 & 3.963178 \\
\hline & & & & & & & \\
\hline Jarque-Bera & 15.96164 & 12.62286 & 13.76504 & 8.726732 & 12.98440 & 12.54285 & 11.57329 \\
\hline Probability & 0.000342 & 0.001815 & 0.001026 & 0.012735 & 0.001515 & 0.001890 & 0.003068 \\
\hline & & & & & & & \\
\hline Sum & 10.44600 & 277.6362 & 272.4388 & 241.3841 & 255.5894 & 253.4890 & 249.2342 \\
\hline Sum Sq. Dev. & 0.083620 & 12.01880 & 12.3600 & 40.57758 & 18.58119 & 13.31027 & 8.062953 \\
\hline & & & & & & & \\
\hline Observations & 24 & 24 & 24 & 24 & 24 & 24 & 24 \\
\hline
\end{tabular}

Source: computed using Views 7.0

Notes: HDI stands for the human development index; AGDP is the agric GDP; OGGP is the oil \& gas GDP; TGDP is telecommunication GDP; MGDP stands the manufacturing GDP; FGDP is financial sector GDP and EGDP is electricity GDP.

The human development index (HDI) averages 0.43 it ranges from 0.27 to 0.50 with a standard deviation of 0.06 in model one. Agric GDP has a mean of 11.56 and varies from a minimum of 11.08 per cent to a maximum of 13.14 per cent with standard deviation of 0.73 per cent respectively. Oil \& Gas GDP (OGGDP) averages 11.35 per cent and varies from 10.92 to 12.96 per cent, with a standard deviation of 1.76 per cent respectively.

Telecommunication GDP (TGDP) averages 10.05 per cent and varies from 9.09 to 12.87 per cent, with a standard deviation of 1.32 per cent respectively. Manufacturing GDP (MGDP) has a mean of 10.64 and varies from a minimum of 10.12 per cent to a maximum of 12.68 per cent with standard deviation of 0.89 per cent respectively. Financial sector GDP (FGDP) averages 10.56 per cent and varies from 9.89 to 12.31 per cent, with a standard deviation of 0.76 per cent respectively. Electricity sector GDP (EGDP) has a mean of 10.38 and varies from a minimum of 9.94 percept to a maximum of 11.75 per cent with standard deviation of 0.59 per cent respectively.

To detect for the normality of the residuals or model errors, the associated probability values of Jarque-Bera statistics have probabilities less than 5 per cent significant level, so the null hypothesis is rejected, which means the error terms in the model are normally distributed. 
Ozurumba Benedict Anayochukwu, Onuorah Anastasia Chi-Chi

Sectorial Performance and Inclusive Growth in Nigeria (1990 - 2013): An Assessment

Table 4.2: Descriptive Statistics of Variables in Model Two

\begin{tabular}{|l|c|c|c|c|c|c|c|}
\hline & GDPPC & AGDPP & OGGDP & TGDP & MGDP & FGDP & EGDP \\
\hline Mean & 3.590734 & 11.56818 & 11.35162 & 10.05767 & 10.64956 & 10.56204 & 10.38476 \\
\hline Median & 3.544886 & 11.27062 & 11.04124 & 9.462023 & 10.23528 & 10.28717 & 10.14741 \\
\hline Maximum & 3.757119 & 13.14714 & 12.96844 & 12.87667 & 12.68171 & 12.31657 & 11.75108 \\
\hline Minimum & 3.515067 & 11.08718 & 10.92474 & 9.091955 & 10.12306 & 9.898355 & 9.947852 \\
\hline Std. Dev. & 0.080573 & 0.722881 & 0.733070 & 1.328248 & 0.898820 & 0.760728 & 0.592084 \\
\hline Skewness & 0.773271 & 1.699167 & 1.763040 & 1.452324 & 1.719364 & 1.689398 & 1.631378 \\
\hline Kurtosis & 2.131317 & 4.036431 & 4.154037 & 3.538283 & 4.076827 & 4.061405 & 3.963178 \\
\hline & & & & & & & \\
\hline Jarque-Bera & 3.146404 & 12.62286 & 13.76504 & 8.726732 & 12.98440 & 12.54285 & 11.57329 \\
\hline Probability & 0.207380 & 0.001815 & 0.001026 & 0.012735 & 0.001515 & 0.001890 & 0.003068 \\
\hline & & & & & & & \\
\hline Sum & 86.17762 & 277.6362 & 272.4388 & 241.3841 & 255.5894 & 253.4890 & 249.2342 \\
\hline $\begin{array}{l}\text { Sum Sq. } \\
\text { Dev. }\end{array}$ & 0.149315 & 12.01880 & 12.36000 & 40.57758 & 18.58119 & 13.31027 & 8.062953 \\
\hline & & & & & & & \\
\hline Observations & 24 & 24 & 24 & 24 & 24 & & 24 \\
\hline
\end{tabular}

Source: E-Views statistical package version 7.0

Notes: GDPPC stands for the GDP Per Capita; AGDP is the agric GDP; OGGP is the oil \& gas GDP; TGDP is telecommunication GDP; MGDP stands for the manufacturing GDP; FGDP is financial sector GDP and EGDP is electricity GDP

In model two, GDP Per Capita (GDPPC) averages 3.59. It ranges from 3.51 to 3.75 with a standard deviation of 0.08 . Agric GDP has a mean of 11.56 and varies from a minimum of 11.08 per cent to a maximum of 13.14 per cent with standard deviation of 0.73 per cent respectively. Oil \& Gas GDP (OGGDP) averages 11.35 per cent and varies from 10.92 to 12.96 per cent, with a standard deviation of 1.76 per cent respectively.

Telecommunication GDP (TGDP) averages 10.05 per cent and varies from 9.09 to 12.87 per cent, with a standard deviation of 1.32 per cent respectively. Manufacturing GDP (MGDP) has a mean of 10.64 and varies from a minimum of 10.12 per cent to a maximum of 12.68 per cent with standard deviation of 0.89 per cent respectively. Financial sector GDP (FGDP) averages 10.56 per cent and varies from 9.89 to 12.31 per cent, with a standard deviation of 0.76 per cent respectively. Electricity sector GDP (EGDP) has a mean of 10.38 and varies from a minimum of 9.94 per cent to a maximum of 11.75 per cent with standard deviation of 0.59 per cent respectively.

To detect for the normality of the residuals or model errors, the associated probability values of Jarque-Bera statistics have probabilities less than 5 per cent significant level, so the null hypothesis is rejected, which means the error terms in the model (except GDPPC) are normally distributed. 
Ozurumba Benedict Anayochukwu, Onuorah Anastasia Chi-Chi

Sectorial Performance and Inclusive Growth in Nigeria (1990 - 2013): An Assessment

\subsection{Stationary Test}

Table 4.3 Summary of Result of Stationary Test

\begin{tabular}{|c|c|c|c|c|c|}
\hline Variable & $\begin{array}{l}\text { ADF- } \\
\text { Value }\end{array}$ & Critical Value & Probability & Decision & $\begin{array}{l}\text { Order of } \\
\text { Integration }\end{array}$ \\
\hline \multirow{3}{*}{ HDI } & & $1 \%=-3.78803$ & & \multirow{3}{*}{ Stationary at 1st difference } & \multirow{3}{*}{$\mathrm{I}(1)$} \\
\hline & $\begin{array}{c}- \\
4.858348\end{array}$ & $5 \%=-3.012363$ & 0.0010 & & \\
\hline & & $10 \%=-2.646119$ & & & \\
\hline \multirow{3}{*}{ LnGDPPC } & & $1 \%=-3.808546$ & & \multirow{3}{*}{ Stationary at 2 nd difference } & \multirow{3}{*}{$\mathrm{I}(2)$} \\
\hline & $\begin{array}{c}- \\
5.970342\end{array}$ & $5 \%=-3.020686$ & 0.0001 & & \\
\hline & & $10 \%=-2.650413$ & & & \\
\hline \multirow{3}{*}{ LnAGDP } & & $1 \%=-3.769597$ & & \multirow{3}{*}{ Stationary at 1st difference } & \multirow{3}{*}{$\mathrm{I}(1)$} \\
\hline & $\begin{array}{c}- \\
4.683849\end{array}$ & $5 \%=-3.004861$ & 0.0013 & & \\
\hline & & $10 \%=-2.642242$ & & & \\
\hline \multirow{3}{*}{ LnOGGDP } & & $1 \%=-3.769597$ & & \multirow{3}{*}{ Stationary at 1st difference } & \multirow{3}{*}{$\mathrm{I}(1)$} \\
\hline & 4.681023 & $5 \%=-3.004861$ & 0.0013 & & \\
\hline & & $10 \%=-2.642242$ & & & \\
\hline \multirow{3}{*}{ LnTGDP } & & $1 \%=-3.769597$ & & \multirow{3}{*}{ Stationary at 1 st difference } & \multirow{3}{*}{$\mathrm{I}(1)$} \\
\hline & $\begin{array}{c}- \\
4.573302\end{array}$ & $5 \%=-3.004861$ & 0.0017 & & \\
\hline & & $10 \%=-2.642242$ & & & \\
\hline \multirow{3}{*}{ LnMGDP } & & $1 \%=-3.769597$ & & & \multirow{3}{*}{$\mathrm{I}(1)$} \\
\hline & $\begin{array}{c}- \\
4.660598\end{array}$ & $5 \%=-3.004861$ & 0.0014 & \multirow[t]{2}{*}{ Stationary at 1 st difference } & \\
\hline & & $10 \%=-2.642242$ & & & \\
\hline \multirow{3}{*}{ LnFGDP } & & $1 \%=-3.769597$ & & \multirow{3}{*}{ Stationary at 1 st difference } & \multirow{3}{*}{$\mathrm{I}(1)$} \\
\hline & $\begin{array}{c}- \\
4.598724\end{array}$ & $5 \%=-3.004861$ & 0.0016 & & \\
\hline & & $10 \%=-2.642242$ & & & \\
\hline \multirow{3}{*}{ LnEGDP } & & $1 \%=-3.769597$ & & & \\
\hline & $\begin{array}{c}- \\
4.252842\end{array}$ & $5 \%=-3.004861$ & 0.0034 & \multirow{2}{*}{ Stationary at 1 st difference } & \multirow{2}{*}{$\mathrm{I}(1)$} \\
\hline & & $10 \%=-2.642242$ & & & \\
\hline
\end{tabular}

Source: Extracts from Result of Stationary Test

From table 4.2 above, the ADF values of the variables are greater than their critical values respectively (absolute term). This therefore, shows that all the variables, except GDPPC, are stationary at first difference. The series contains one unit root and are integrated of order one, I(1). GDPPC on the other hand is stationary at second difference and is integrated of order two, I(2). Having established that the variables are stationary, we conducted the counteraction test using Johansen integration method. This test is conducted to determine if long-run relationship exists among the variables. 
Ozurumba Benedict Anayochukwu, Onuorah Anastasia Chi-Chi

Sectorial Performance and Inclusive Growth in Nigeria (1990 - 2013): An Assessment

\subsubsection{Counteraction Test}

Table 4.4.1: Summary of counteraction Test (Model 1)

\begin{tabular}{|c|c|c|c|c|c|c|c|c|}
\hline $\begin{array}{c}\text { Hypothesi- } \\
\text { zed } \\
\text { No. of CE(s) }\end{array}$ & Eigenvalue & $\begin{array}{c}\text { Trace } \\
\text { Statistic }\end{array}$ & $\begin{array}{c}0.05 \\
\text { Critical } \\
\text { Value }\end{array}$ & Prob.** & $\begin{array}{c}\text { Hypothesi- } \\
\text { zed } \\
\text { No. of CE(s) }\end{array}$ & $\begin{array}{c}\text { Max-Eigen } \\
\text { Statistic }\end{array}$ & $\begin{array}{c}0.05 \\
\text { Critical } \\
\text { Value }\end{array}$ & Prob.** \\
\hline None * & 0.999970 & 450.1542 & 125.6154 & 0.0001 & None * & 229.4536 & 46.23142 & 0.0000 \\
\hline At most $1 *$ & 0.988319 & 220.7006 & 95.75366 & 0.0000 & At most $1 *$ & 97.89626 & 40.07757 & 0.0000 \\
\hline At most $2 *$ & 0.949532 & 122.8044 & 69.81889 & 0.0000 & At most $2 *$ & 65.70095 & 33.87687 & 0.0000 \\
\hline At most $3 *$ & 0.796280 & 57.10342 & 47.85613 & 0.0053 & At most $3 *$ & 35.00215 & 27.58434 & 0.0046 \\
\hline At most 4 & 0.479688 & 22.10126 & 29.79707 & 0.2929 & At most 4 & 14.37321 & 21.13162 & 0.3352 \\
\hline At most 5 & 0.296006 & 7.728056 & 15.49471 & 0.4949 & At most 5 & 7.721680 & 14.26460 & 0.4077 \\
\hline At most 6 & 0.000290 & 0.006377 & 3.841466 & 0.9358 & At most 6 & 0.006377 & 3.841466 & 0.9358 \\
\hline
\end{tabular}

Source: Extract from counteraction Test

Table 4.4.1 shows the counteraction result for model 1 , the trace test as well as the max-Eigen test indicates 4 counteracting equations respectively at the 0.05 level. This led to the conclusion therefore, that long run relationship exists between the sectorial performance and the human development index used in model 1.

Table 4.4.2: Summary of counteraction Test (Model 2)

\begin{tabular}{|c|c|c|c|c|c|c|c|c|}
\hline $\begin{array}{l}\text { Hypothesized } \\
\text { No. of CE(s) }\end{array}$ & Eigenvalue & $\begin{array}{c}\text { Trace } \\
\text { Statistic }\end{array}$ & $\begin{array}{c}0.05 \\
\text { Critical } \\
\text { Value }\end{array}$ & Prob.** & $\begin{array}{l}\text { Hypothesized } \\
\text { No. of CE(s) }\end{array}$ & $\begin{array}{c}\text { Max- } \\
\text { Eigen } \\
\text { Statistic }\end{array}$ & $\begin{array}{l}0.05 \\
\text { Critical } \\
\text { Value }\end{array}$ & Prob.** \\
\hline None * & 0.994171 & 330.2576 & 125.6154 & 0.0000 & None * & 113.1864 & 46.23142 & 0.0000 \\
\hline At most $1 *$ & 0.989604 & 217.0712 & 95.75366 & 0.0000 & At most $1 *$ & 100.4586 & 40.07757 & 0.0000 \\
\hline At most $2 *$ & 0.879171 & 116.6125 & 69.81889 & 0.0000 & At most $2 *$ & 46.49440 & 33.87687 & 0.0010 \\
\hline At most $3 *$ & 0.793591 & 70.11813 & 47.85613 & 0.0001 & At most $3 *$ & 34.71372 & 27.58434 & 0.0051 \\
\hline At most $4 *$ & 0.677078 & 35.40441 & 29.79707 & 0.0102 & At most $4 *$ & 24.86756 & 21.13162 & 0.0142 \\
\hline At most 5 & 0.324842 & 10.53685 & 15.49471 & 0.2417 & At most 5 & 8.641780 & 14.26460 & 0.3172 \\
\hline At most 6 & 0.082534 & 1.895068 & 3.841466 & 0.1686 & At most 6 & 1.895068 & 3.841466 & 0.1686 \\
\hline
\end{tabular}

Source: Extract from counteraction Test.

Table 4.4.2 shows the counteraction result for model 2 . Thus, the trace test as well as the max-Eigen test indicates 5 counteracting equations respectively at the 0.05 level. This led to the conclusion therefore, that long run relationship exists between the sectorial performance and the GDP per capita used in model 2.

\subsection{Regression Test}

Table 4.5.1: VAR Result - Dependent Variable: HDI (Model1)

\begin{tabular}{|lccc|}
\hline Variable & Coefficient & Std. Error & t-Statistic \\
$5 \%$ & & & \\
\hline C & 4.134912 & 3.23098 & 1.27977 \\
LnAGDP & 2.492238 & 0.63882 & 3.90134 \\
LnOGGDP & 0.446457 & 0.25700 & 1.73719 \\
LnTGDP & -1.952988 & 0.29842 & -6.54444 \\
LnMGDP & -0.281554 & 0.23522 & -1.19699 \\
LnFGDP & 0.103847 & 0.43825 & 0.23696 \\
LnEGDP & -0.127688 & 0.46388 & -0.27526 \\
\hline R-Squared & 0.978120 Adj. R-Squared 0.934359 F-Statistic \\
22.35165 & & & \\
\hline
\end{tabular}

Source: Extract from VAR Test 
VAR Model - Substituted Coefficients:

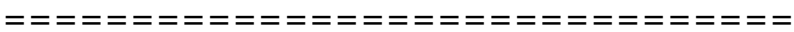

$\mathrm{HDI}=4.134912+2.492238 *$ LnAGDP $+0.446457 *$ LnOGGDP $-1.952988 *$ LnTGDP -

$0.281554 *$ LnMGDP + 0.103847*LnFGDP - 0.127688*LnEGDP + 4.134912

Considering the regression result for model 1, as presented in table 4.4, the coefficient of Agricultural sector contribution to Gross Domestic Product (AGDP) is 2.492238. This implies that there is positive relationship between AGDP and HDI, in the short-run such that a unit change (increase) in AGDP will cause HDI to increase by 2.49units, ceteris paribus. That is the higher the investment in Agriculture, the higher its contribution to GDP and this will result to improved development of the economy and the citizenry, all things being equal. This relationship is statistically significant at $5 \%$ level. The variable (OGGDP), which is the contribution of Oil and Gas sector to Gross Domestic Product, has a positive coefficient of 0.446457 . This positive relationship implies that as OGGDP increase by 1 unit, HDI will be expected to increase by 0.45 unit, all things being equal. However, this positive relationship is not statistically significant at $5 \%$ level.

Contrary to the above result, Telecommunication sector contribution to Gross Domestic Product (TGDP) has a statistically significant relationship with HDI but this relationship is inverse, indicating that as TGDP increases by 1 unit, HDI will dwindle to the tune of 1.95 units, ceteris paribus. MGDP and EGDP respectively, have negative and insignificant relationships with HDI. Their coefficients of 0.281554 and -0.127688 is an indication that HDI will dwindle by 0.28 unit and 0.13 unit as MGDP and EGDP increase by 1unit respectively. On the contrary, FGDP has positive relationship with HDI such that 1unit increase in FGDP will cause HDI to increase by 0.24 unit, all things being equal. This relationship is not statistically significant at $5 \%$. It should be noticed that the constant value is positive showing that at zero performance of the variables, HDI will increase. This is not significant and can be ignored.

Considering the coefficient of determination, the adjusted $\mathrm{R}^{2}$ shows that about $93.44 \%$ of the total variation in Human Development Index is determined by changes in the explanatory variables while $6.56 \%$ of the variations in the dependent variable are explained by other variables not explained by the model. Again, the $\mathrm{R}^{2}$ value of $97.81 \%$ shows that the model is good fitted. The F-statistics (22.35) indicates that the explanatory variables are jointly statistically significant at $5 \%$ level.

Table 4.5.2 VAR Result: Dependent Variable: GDPPC (Model 2)

\begin{tabular}{|lcccc|}
\hline Variable & Coefficient & Std. Error & t-Statistic & \\
\hline C & -0.327350 & 3.71598 & -0.08809 & \\
LnAGDP & 0.137567 & 0.28070 & 0.49009 & \\
LnOGGDP & -0.122954 & 0.17663 & -0.69813 & \\
LnTGDP & -0.128882 & 0.15434 & -0.83505 & \\
LnMGDP & -0.101977 & 0.11697 & -0.87179 & \\
LnFGDP & 0.138318 & 0.13632 & 1.01464 & \\
LnEGDP & 0.218759 & 0.22768 & 0.96080 & \\
\hline R-Squared & 0.998396 & Adj. R-Squared & 0.995187 & F- \\
Statistic 311.1830 & & & \\
\hline
\end{tabular}

Source: Extract from VAR Test.

VAR Model - Substituted Coefficients:

$=====================$

LnGDPPC $=-0.327350+0.137567 *$ LnAGDP $-0.122954 *$ LnOGGDP $-0.128882 *$ LnTGDP -

$0.101977 *$ LnMGDP + 0.138318*LnFGDP + 0.218759*LnEGDP -0.327350

The VAR result for model 2 (table 4.5.2), shows that AGDP, FGDP and EGDP have positive relationship with GDPPC. Their coefficients are $0.137567,0.138318$ and 0.218759 respectively. A unit increase in AGDP, FGDP and EGDP respectively will lead to increase in GDPPC to the tune of 0.14unit, 0.138 unit 
and 0.22 unit, all things being equal. This positive relationship conforms to a priori expectation but is not statistically significant. Since finance is the resource that connects all various sectors of the economy, providing solutions for financing social services, growing the real sector is very critical to our socio-economic development. The contribution of the financial sector GDP is of critical importance considering the intermediation role it plays to stimulate economic activities in a manner that creates linkages across economic value chains. Unfortunately this has not been realized given the bottlenecks in extending financial services to the real sectors in our economy as depicted by the insignificant nature of our results.

Conversely, OGGDP, TGDP and MGDP have coefficients of $-0.122954,-0.128882$ and -0.101977 , showing inverse relationship between them and GDPPC with the indication that 1unit increase in OGGDP, TGDP and MGDP will cause GDPPC to decrease by 0.12 unit, 0.13 unit and 0.10 unit, ceteris paribus. This negative relationship does not conform to a priori expectation and are not statistically significant at $5 \%$. However, the above results depict the real situation with regards to the performance of the various sectors namely: oil and gas, telecommunication and manufacturing. For instance, the country sells crude oil and imports refined petroleum products that are sold at a price far above the crude oil price. The situation is now worse considering the oil glut and the economy's much reliance on revenue from oil. The telecommunication is more in the area of sale of recharge cards as against manufacturing of cell phones and accessories and the accompanied technology. Also, the manufacturing sector is operating below optimum capacity as many Nigerians have penchant for foreign made goods as against locally produced ones. Again, most manufacturers suffer the high cost of production due to persistent erratic power supply that has defiled solutions. This has caused some companies like PZ, Michelin, Dunlop and others to shut down their subsidiaries in Nigeria and relocated to Ghana and some other countries. All these combined have continued to worsen the our GDP per capita and human development index. Life expectancy, income-inequality, illiteracy, fallen living standards, high mortality rate, unemployment and other social vices have been on the increase.

\subsection{Causality Test}

Table 4.6: Summary of Result of Causality Test (Model 1)

Pairwise Granger Causality Tests

Date: 09/07/15 Time: 05:47

Sample: 19902013

Lags: 2

\begin{tabular}{lrrr}
\hline \hline Null Hypothesis: & Obs & F-Statistic & Prob. \\
\hline \hline LnAGDP does not Granger Cause HDI & 22 & 1.34141 & 0.2878 \\
HDI does not Granger Cause LnAGDP & & 0.59733 & 0.5614 \\
\hline \hline LnOGGDP does not Granger Cause HDI & 22 & 1.06183 & 0.3677 \\
HDI does not Granger Cause LnOGGDP & & 0.64612 & 0.5365 \\
\hline \hline LnTGDP does not Granger Cause HDI & 22 & 1.99558 & 0.1665 \\
HDI does not Granger Cause LnTGDP & & 0.32280 & 0.7285 \\
\hline \hline LnMGDP does not Granger Cause HDI & 22 & 1.28915 & 0.3011 \\
HDI does not Granger Cause LnMGDP & & 0.62740 & 0.5459 \\
\hline \hline LnFGDP does not Granger Cause HDI & 22 & 1.26580 & 0.3073 \\
HDI does not Granger Cause LnFGDP & & 0.76658 & 0.4800 \\
\hline \hline LnEGDP does not Granger Cause HDI & 22 & 1.64991 & 0.2214 \\
HDI does not Granger Cause LnEGDP & & $\mathbf{0 . 5 0 5 6 8}$ & $\mathbf{0 . 6 1 1 9}$ \\
\hline \hline
\end{tabular}


Source: Extract from Result of Causality Test.

Considering the coefficient of determination, the adjusted $\mathrm{R}^{2}$ shows that about $99.52 \%$ of the total variation in Gross Domestic Product Per Capita is determined by changes in the explanatory variables while $0.48 \%$ of the variations in the dependent variable are explained by other variables not explained by the model. Again, the $\mathrm{R}^{2}$ value of $99.84 \%$ shows that the model is good fitted. The F-statistics (311.18) indicates that the explanatory variables are jointly statistically significant at $5 \%$ level. At zero performance of the explanatory variables, GDPPC will be negative as indicated by negative constant value.

From the result in table 4.7, the causality test results show that the Agric GDP(AGDP); Oil \& gas GDP(OGGP); Telecommunication GDP (TGDP); Manufacturing GDP(MGDP); Financial sector GDP(FGDP) and Electricity sector GDP(EGDP) do not granger cause Human development index(HDI) and Human development index(HDI) does not in turn granger causes the various sectorial GDP in Nigeria within the period under review. Therefore, there is no equilibrium run relationship among the selected sectorial GDP and Human development index in Nigeria.

Table 4.7: Summary of Result of Causality Test (Model 2)

\begin{tabular}{|lccc|}
\hline Null Hypothesis: & Lag & $\begin{array}{c}\text { F- } \\
\text { Statistic }\end{array}$ & Prob. \\
\hline LnAGDP does not Granger Cause LnGDPPC & 2 & 3.49287 & 0.0536 \\
LnGDPPC does not Granger Cause LnAGDP & & 3.59573 & 0.0499 \\
\hline LnOGGDP does not Granger Cause LnGDPPC & 2 & 4.00422 & 0.0376 \\
LnGDPPC does not Granger Cause LnOGGDP & & 3.50450 & 0.0532 \\
\hline LnTGDP does not Granger Cause LnGDPPC & 2 & 2.90981 & 0.0819 \\
LnGDPPC does not Granger Cause LnTGDP & & 4.11835 & 0.0348 \\
\hline LnMGDP does not Granger Cause LnGDPPC & 2 & 3.41110 & 0.0568 \\
LnGDPPC does not Granger Cause LnMGDP & & 3.84327 & 0.042 \\
\hline LnFGDP does not Granger Cause LnGDPPC & 2 & 2.76699 & 0.0911 \\
LnGDPPC does not Granger Cause LnFGDP & & 3.33101 & 0.0602 \\
\hline LnEGDP does not Granger Cause LnGDPPC & 2 & 2.75205 & 0.0922 \\
LnGDPPC does not Granger Cause LnEGDP & & 3.67776 & 0.0471 \\
\hline
\end{tabular}

Source: Extract from Result of Causality Test

From the result in table 4.8 (Model 2), GDPPC stands for the GDP Per Capita; AGDP is the agric GDP; OGGP is the oil \& gas GDP; TGDP is telecommunication GDP; MGDP stands the manufacturing GDP; FGDP is financial sector GDP and EGDP is electricity GDP.

There is also unidirectional (one -way) granger causality running from GDP Per Capita (GDPPC) to agric GDP (AGDP), telecommunication GDP (TGDP), manufacturing GDP (MGDP) and electricity GDP (EGDP) as the associated probability values are less than the 0.05 at 5 per cent critical level. That is, causality runs without feedback implying that the increase or decrease in AGDP, TGDP, MGDP and EGDP separately may be as a result of increase or decrease in GDPPC. Only Oil \& Gas GDP (OGGDP) granger causes GDP Per Capita (GDPPC). Thus, the increase or decrease in GDPPC may be as a result of increase or decrease in OGGDP. However, there is no causal relationship between Financial sector GDP (FGDP) and GDP Per Capita (GDPPC) in Nigeria within the period under review. This confirms the case of financial exclusion that has been witnessed in the country over time which has hampered the level of economic development in Nigeria. 


\section{SUMMARY AND CONCLUSION}

This work assessed the effect of Sectorial Performance on Inclusive Growth in Nigeria for the period 1990 - 2013. The work employed secondary data sourced from CBN statistical Bulletin while some tests carried out include: stationary, counteraction and vector autoregressive (VAR) tests. The descriptive test result indicates that the data set are normally distributed. The stationary test carried out using augmented dickey fuller (ADF) showed that all the variables, except GDPPC, are stationary at first difference. The tests established a long run relationship between sectorial performance and inclusive growth as confirmed by the VAR results. The F-statistics (311.18) indicates that the explanatory variables are jointly statistically significant at $5 \%$ level. There was no causal relationship between HDI and all the selected sectorial performance. However, there was a unidirectional (one way) granger causality running from GDP Per Capita (GDPPC) to agric GDP (AGDP), telecommunication GDP (TGDP), manufacturing GDP (MGDP) and electricity GDP (EGDP). On the other hand, Oil \& Gas GDP (OGGDP) granger causes GDP Per Capita (GDPPC) while no causal relationship between Financial sector GDP (FGDP) and GDP Per Capita (GDPPC) was found within the period under review. Based on the findings the work concludes that the different selected sectors of the economy have not contributed significantly to the development of the Nigerian economy despite the much orchestrated economic rebasing. They contribute to the gross domestic product which is a good measure of economic growth but such growth has not been inclusive. The citizens have not felt the impact of such growth. This conclusion is evidenced by the insignificant relationship witnessed between the sectorial contributions and selected economic development indicators (HDI and GDPPC). There is need to improve on the performance of the various sectors of the economy in order to achieve a sustainable growth. Efforts should be made to ensure that financial sector services to the real sector are sustainable to stimulate economic activities in a manner that creates linkages across economic value chains that will assure inclusive growth in the long run.

\section{REFERENCES}

- AFDB (2012). Asian Development Outlook 2012: Confronting Rising Inequality in Asia. Mandaluyong City, Philippines, Asian Development Bank.

- Anders, O. K., \& Sperling, L.L. (2013). Measuring Inclusive Growth Experiences- Five Criteria for Productive Employment. A conference paper submitted for presentation at UNU-WIDER's conference, held in Helsinki on 20-21 September 2013.

- Azariadis, C., \& Drazen, A. (1990). "Threshold externalities in economic development", The Quarterly Journal of Economics, 105(2), 501, CrossRef

- CBN (2013). "Modelling the Real Sector of the Nigerian Economy", Central Bank of Nigeria, Abuja, Research Department.

- Central Bank of Nigeria (2013). CBN Statistical Bulletin, Vol. 24, Abuja.

- Cochrane, J.H. (2005): Time series for macroeconomic and finance; University of Chicago 5807 S. Woodlawn.

- Elena, I., \& Sushana, L. (2010), "Inclusive Growth Analytics: Framework Policy Research. World Bank, Economic Policy and Debt Department, Economic Policy Division WP:No.4851.

- Eluhaiwe, P.N. (2010). "The Central Bank of Nigeria Partnership with Alliance for a Green Revolution in Africa (AGRA): Conceptual Issues, Operations and Prospects for Food Security in Nigeria", Financial Review, Central Bank of Nigeria.

- George, J. (2011), "Growth and Development. Inclusive Growth: What went wrong with Development?"

- Gujarati, D. N. (2004): Basic Economics, Fourth Edition: Tata McGraw-Hill Publishing Company Ltd, New Dehi.

- Harrod, R.F. and E.D. Domar, (1946), "Capital Expansion, Rate of Growth and Employment", Econometrica, 14, April.

- Harrod, R. F. (1948). Towards a dynamic economics, some recent developments of economic theory and their application to policy. London: Macmillan.

- Hein, S. (1992). Trade strategy and the dependency hypothesis: A comparison of policy, foreign investment, and economic growth in Latin America and East Asia. Economic Development and Cultural Change, 40(3), 495-521, CrossRef

- Koutsoyiannis, A. (2003). Theory of Econometrics, 4th edition, London, the Macmillan Press Ltd.

PMid: 12771459 
- Lewis, W. A. (1954). Economic development with unlimited supplies of labour. The Manchester School, 22(2), 139-191, CrossRef

- Meier, G. M. (2000). The old generation of development economists and the new. In G. M. Meier \& J. E. Stiglitz (Eds.), Frontiers of development economics: The future in perspective (pp. 13-50). Washington, D.C.: World Bank/Oxford University Press, CrossRef

- Mordi, C.N.O., Englama, A. and Adebusuyi, B.S.(2010). "The Changing Structure of the Nigerian Economy" Central Bank of Nigeria, Abuja, Research Department.

- Onwioduokit, E. A. (1999). "Government and Economic Development: Further Evidence from Nigeria", CBN Research Department Seminar Paper Series No.7.

- Ranieri, R., \& Ramos, R. A.(2013). Inclusive Growth: Building Up a Concept. International Policy Centre for Inclusive Growth (IPC-IG). Working Paper number 104, March, 2013.

- Rostow, W. W. (1960). The stages of economic growth: A non-communist manifesto. Cambridge: Cambridge University Press.

- Todaro, M., \& Smith, S. (2009). Economic development (10th ed.). Boston: Addison Wesley.

- World Bank. (2000). Entering the 21st century-World development report 1999/2000. New York: Oxford University Press. 